now so dilated, that I could pass my hand round the body, but the heads were still so high and wedged that it was impracticable to turn-then feeling for the legs, with great care I drew them down, the bones of which were so flexible that they bent double. Drawing still with considerable force, the navel appeared and then the remainder of the body (the uterus having now the power of contraction from the vacuum that was furnished) was expelled with very little difficulty, the placenta with a clouble cord following immediately. Such had been the lose of blood from the arm and uterus, that syncope now took place to a very alarıning degree, and it was with the greatest difficulty, with frictions and cordials, she was restored. It may be proper to add, that opium was occasionally combined with the lancet in such doses as to co-operate with the debilitating effects thereof, and with evident advantage, particularly when the pains did not approach regularly and there was any hemorrhage. This is the 15th day of her delivery, and except a great degree of debility which must necessarily happen, she exhibits a promising prospect of recovery.

Weight of child $151 b$.

2 Heacls,

4 Superior extremities,

3 Inferior do.

7 Toes on club foot.

Greenville, North Carolina, Afril, 1816.

\title{
SOME ACCOUNT OF THE GRAND MONADNOCK.
}

\section{BY J. FRERMAN DANA, A. B.}

Member of the New-England Linnean Society.

[For the New England Journal of Medicine, \&c.]

Thr branches of the Merrimack and Connecticut rivers are separated by a lofty ridge of mountains called the height of land, in which is situated the Grand Monadnock, about twenty-two miles east of Connecticut river, and ten north of the southern boundary of the State of New-Hampshire, in the towns of Jeffrey and Dublin. The direction of the ridge is N. E. and S. W. 
the mountain is five iniles long from $N$. to $S$. and three from E. to W. The country around it is formed of Mica Slate, (common, very large hills and mountains of which run through Peterborough, New-Ipswich, \&c. A large proportion of sulphuret of iron occurs in this rock, in a state of decomposition, the rock falling into pieces; a few grains of it in this state when dif. fused in four or five cubic inches of water will exhibit strongly the characteristics of iron on the addition of the triple prussiate of potash, or tincture of galls.

The summit of the mountain, when seen at the distance of four or five miles, appears rouncled and destitute of those high cliffs and mural precipices belonging to granitic mountains. The mountain is composed of the Talcy mica Slatc, distinctly stratified; the strata are from one foot to three feet in thickness, and dip towards the north at an angle of about 300 ; garnets in large quantities are imbedded in the rock, and the mountain is taversed by veins of compact black schorl, which is always accompanied with white quartz running north and south; the schorl often forms the face of precipices. From the vertical position of the strata, it is inferred that where any rock breaks out at the surface, they continue the same through the whole mountain in the direction of a perpendicular plane; wherever I had an opportunity to trace the strata or veins they continued the same.

Feldspar, in large crystals sometimes occur in this rock; where the crystals are exposed to the atmosphere they are decomposed.

Schorl occurs in crystals, very large, disseminated, and in masses composed of snall crystuls aggregated.

Quartz, occurs in large masses, and the surface of it which has becn exposed to the action of the atmosphere has acquired the lustre and appearance of enamel, and totally different from a fresh fiacture.

Plumbago, is found in consiclerable quantities on the north side of the mountain; it has not yet been applied to any useful purpose, but might be employed in civil and domestic economy.

A small stream of water rises near the summit of the moun. tain, and dividing, runs down on the north and south sides. The prospect from the pinacle is very extensive; thirty ponds of fresh water, some of which are so large as to contain islanels of VoL. $\mathrm{V}$. 
254

ACCOUNT OF THE GRAND MONADNOCK.

eight or ten acres, may be seen from it, in the immediate vicipity.

The mineral which constitutes this mountain shews it to be among the primitive rocks, and hence we may know what chedit to attach to the reports that volcanic plienomena lave been observed on this mountain, and that the rocks in some places bear the marks of having been heated, and calcined; on atenfive examination not the slightest trace of a volcano could be discovered, nor can we conjecture on what these reports were founded; some specimens of massive schorl, which occur lice might be mistaken for scoriae by the ignorant.

The height of the Monadnock was ascertained in 1780, by James Winthrop, Esq, of Cambridge, by Barometrical admeasurement and the corresponding heights in Martin's Philos. Bitannica; difference of temperature was not regarded, and the barometer was filled for each observation. Many improvements have been introduced into this mode of determining altitudes since that time, and it was therefore judged proper to repeat the observations, making necessary correction for temperature. The instruments used were the improved mountain barometer of Sir H. C. Finglefield, corrected by the standard barometer of the University, and a best mercurial thermometer by Junes. The observations were made on the 2 I st of May, on the north side of the mountain.

$$
9 \text { o'clock } 30^{\prime} \text { A. M. }\left\{\begin{array}{cl}
\text { at the base, (a) Barm. } & \begin{array}{c}
28,894 \\
\text { Thermom. }
\end{array} \\
2 \text { P. M. }\left\{\begin{array}{c}
680 \text { Fat: } \\
\text { Top Barometer }
\end{array}\right. & 26,868 \\
\text { Thermometer } & 560 \text { F. }
\end{array}\right.
$$

2 P. M. the Barometer at the University by Professor Farrar,

29,990

Thermometer

$57 \circ$ F.

From these data, by the formula given in Taylor's logarithms, which is the mean of Shuckburgh's and Gen. Roy's, the height above the level of the sea is 3450 feet, and above the base, $1997,5$. $x$

Near the base of the mountain is the "Monadnock Mineral Spring ;" it issues near a small stream of fresh water, and

(a) Judge Winthrop's observations were on the same side of the nountain,

$\begin{array}{cc}\text { Barometer, Bottom } & 28,4 \\ \text { Top } & 26,4\end{array}$

-
For personal use only. No other uses without permission. From the NEJM Archive. Copyright $\odot$ 2010 Massachusetts Medical Society. 
yields 14 quayss per minute; I found its temperature 580 Faht. and it has beet known to freeze. The channels, \&c. through which the water has been rumning for several years, are covered with a coat of red oxjde of iron and the water is slightly chalybeate to the breatig following experiments were made on the water at the fountain head.

Experiment 1. To a portion of water inmediately from the spring, a few drops of the infusion of litmus were added; but no change of colour could be perceived.

Exp. 2. To a like portion of water which had been boiled, infusion of litmus was adcled in the same proportion, on compa. rison no shade of difference was perceptible between it and that used in the first experiment.

Exp. 3. Oxalate of ainmonia or solution of pure barytes when added to this water produced no change.

Exp. 4. Solution of sub-acetate of lead, when added to water produced a blueish coloured precipitate, which instantly became white and opaque. On the addition of a few drops of nitric acid, the precipitate was re-dissolved.

Fpx. 5. Solution of muriate of barytes produced a slight precipitate which was immediately dissolved by nitric acid.

Exp. 6. Crystals of ferruretted chyazate of potass (triple prussiate) were dissolved in pure distilled water, and a few drops of the solution were added to the spring water but no change ensued.

Exp. 7. Tincture of galls when added to the water produced no. change, but on suffering them to stand in contact a few days a slight brownish colour was produced.

Exp. 8. Soap dissolved in alcohol was not decomposed when added to this water, and agitation instantly presented the phe. nomena of soft waters.

From these experiments we infer that the water of this spring holds in solution a minute quantity of carbonate of iron, but the proportion so small as scarcely to entitle it to the appellation of

\section{a Mineral water.}

After having stated the above facts respecting the mountain and its vicinity, it may not be uninteresting to give a general view of the geology of the country over which we passed, between Boston and the Monadnock; with a more particular description of the individual specimens we found, together with. their localities. 
Clay-slace and greenstone occur in Cambridge forming those hills famous in the revolution for the encampment of the Americhn armies, their direction is $\mathrm{N}_{\text {r }}$ and $\mathrm{S}$. near them is found bog iron ore.

Greenstone forms ranges of hills in Woburn, West-Cambriclge, Waltham, Watertown and Weston. At.Woburn Gneiss occurs, and is traversed by a considerable vein of copper pyrites accompanied with iron. At Concord, greenstone occurs, and a large vein of sulphuret of iron in a decomposing state is found in it ; veins of carb. lime traverse the greenstone at this place ; lime stone is found in large quantities at Bedford, and is $\mathrm{cm}$ ployed in the arts. Bog ore of iron is found at Concord. Mica slate is found at Acton and Littleton; and at Westford fine staly soft talc. Clay-slate again'appears at Groton, and this formation continues throtigh the towns of Pepperell and Hollis to Amherst, N. H. where an alluvial deposit is found. Bog ore of iron is found at Groton and has been wrought. Large masses of granite are frecquently found in these towns but no mountain masses. Mica slate forms the remainder of the country liom the vicinity of Groton to the summit of the Monadnock. A large granite hill is found in New Ipsivich, but whether it is a mountain mass is questionable; we had no opportunity to examine it satisfactorily.

We found the following minerals which we present to the Socicty.

Quartz, colourless and transparent; smoky, in the granite hill New Ipswich, Monadnock-white semitransparent and reddish, Monacinock.

Beryl, a large six sided crystal. New Ipswich.

Feldsfiar, common, white, in large crystals-Mk.-New Ipse wich-Amlserst N. H. reddish-Mk.-

Disintigrated, forming the porcelain earth, (abundant) N. Ipswich, Mica, massive, greenish white passing to white, pseuda metallic lustre, New Ipswich-greenish-Mk.

Schos'l, Black, massive, compact, and in masses composed of small aceicular, parallel and diverging crystals $-\mathrm{Mk}-\mathrm{N}$. Ipswich, crystalized and imbedded-Mk.

Garnct, coinmon, imbedded in mica Slate-Mk.-in graniteWilton N. H. Iron, Magnetic ore, crystallized rhomboidal dodecabedron, imbedded in granite, or disseminated in veins of felclspar traversing granite, Amherst N. H. 
Bog ore, earthy - Groton -in masses with a resinous fracture, Groton and Concord. The iron manufactured from this ore obtains through the country the name of Groton iron, it is in fact the hot-short iron, not capable of being welded under com. mon circumstances; the sniths observe that a peculiar odour arises from it when heated.and hence probably it contains arsenic, which has been imagined to be the cause of this peculiarity in iron. I have not had opportunity to examine it more miuutely. Plumbago-North side of the Monadnock.

I an under many obligations to my brother Mr. S. L. Dana, F. L. S. N. E. and to Wn. White, Esq. of Watertown, who aecompanied ime, for much assistance in collecting the above facts and observations-and if this account shall make known any new fact to the society, or shall lead mure able members to communicate the result of their observations, it will have attained its highest object.

Cambridge, June 8, 1816.

\section{APPENDIX.}

[For the New-England Journal of Medicine, \&c.]

A knowledge of the relative heights and position of hills, the direction of the strata and rocks of which they are composed, are very essential towards forming a geological history of our country. The heights may be ascertained with sufficient accuracy by barometrical admeasurement; many persolis who are possessed of a barometer entertain an erroneous idea that the method of determining altitudes by it is very laborious and difficult, but the rules for effecting this are abundantly simple; it is not necessary for one to klow that when the heights form an arithmetical progression the corresponding densities of the air are in a geometrical progression, \& c. or even the principle on which the instrument is constructed ; the mariner easily determines his latitude without a knowledge of astronomy, and the carpenter, ignorant of geometry often squares his work by a practical application of Euclicl's 47th Proposition. Our common books do not contain formula for determining altitudes by the barometer, and I have therefore subjoined the following rules. 
For the purpose of computing on the spol, and very near the truth, any observations, the following short table: and method of using it by Sir H. C. Euglefield will be found very convenient. It expresses the value of the difference of the tenth of an inch in the height of the mercury at the temperature of freezing water, in English feet.

TABLE.

\begin{tabular}{|c|c|c|c|c|c|c|c|}
\hline Inches & tond & Inches & Fret & Inches & [Feet] & |Inches| & Fe \\
\hline 20,05 & $1 . j \mathrm{~J}$ & 22,25 & 111 & 25,05 & I04 & 28,35 & $\overline{92}$ \\
\hline ,20 & 129 &, 45 & 116 & ,30 & 103 & .65 & \\
\hline 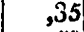 & 128 & ,65 & 115 &, 55 & 102 & ,95 & \\
\hline 50 & 127 & 85 & 114 &, 80 & 101 & 29,27 & \\
\hline 66 & 126 & 23,05 & 113 & 26,05 & 100 &, 61 & \\
\hline, 82 & 125 & ,25 & 112 & 30 & 99 &, 95 & 8 \\
\hline 21,00 & 124 & ,4.5 & 111 &, 57 & 98 & 30,30 & o \\
\hline, 18 & 123 & 65 & 110 & ,85. & 97 & ,65 & 0 \\
\hline 35 & 122 & 87 & 109 & 27,15 & 96 & 31,00 & 0 \\
\hline & 121 & 24,10 & 108 &, 45 & 95 &, 37 & 8 \\
\hline & 120 & ,32 & 107 &, 75 & 94 &, 75 & 8 \\
\hline , & 119 &, 55 & 106 & 28,05 & 93 & 32,10 & 8 \\
\hline 22,0 & 118 & & 105 & & & & \\
\hline
\end{tabular}

The method of determining altitudes by the help of this table is as follows : 1st. Add the two observed heights of the Barometer together and halve the sum to obtain the mean height. 2 d. Subtract the lesser height from the greater, the remainder is of: course the difference of heights in tenths, \&c. of an inch. 3d. Entcr the table with the mean height, and take out the feet answering 10 it making a proportion if the mean height does not answer. exactly to a fuot. 4.th. Multiply the number thus obtained by the tenths, \& $\mathrm{c}$. of an inch of the difference of height of mercury in the Barometer tube, and the result will be nearly the same number ot feet answering to the difference of height between the two barometers $\dot{q} t$ the temperaturc of freezing water.

For the purpose of immediate computation, the correction of the heights thus obtained for temperature, is made by the following rule of Sir H. C. Engleficld. For every four degrees that the mean temperature of the two detached thermometers exceeds 320 of Faht. add one luundredth of the approximate: height before obtained, to it ; for every 400 one tenth, and 80 for any greatcr or less number of degrees. 
When the barometer stands betsueen 29 and 30 inches and the elevation does not exceed $1.500 \mathrm{fcet}$, the above nules will give the height within one foot of the.logatithmic method; if the elevation be about $\mathbf{3 0 0 0}$ feet the error is $\$$ feet, and at beights greater than 3000 feet the error increases in a higher ratio. Pages stiould be prepared in the following way for registering.

BAROMETRICAL OBSERVATIONS.

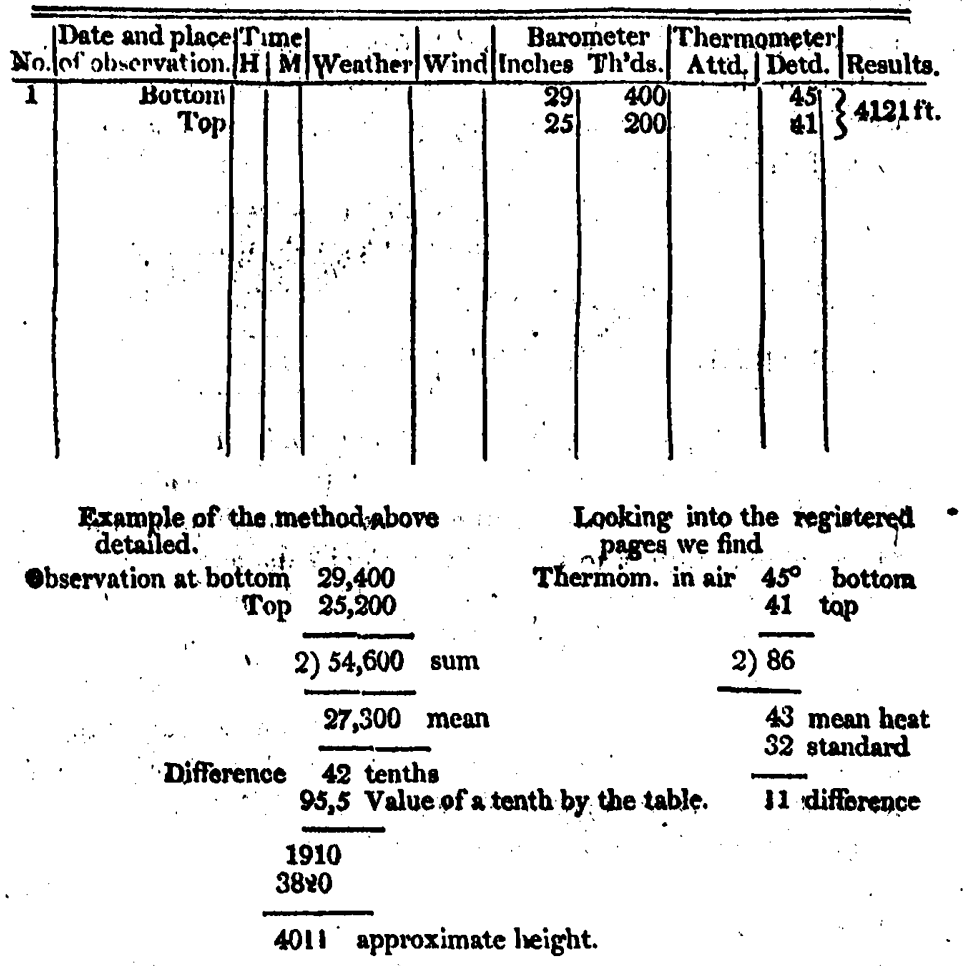

Gorrection for temperature, for $8^{\circ}-2$ hundredth6 -80 feet for $3^{\circ}-3$ hundredths -30 feet

$\begin{aligned} & \text { Approximate height- }-4011 \\ & \text { Correction }\end{aligned}$
$\frac{110}{4121 \text { feet. }}$

For more rigid calculation the Logarithmic method may be used. The altitudes of the Barometer at the two stations, with 
the heights of Fahts. Thermometer attached to the Barometer, and the heights of two Thermometers of the same kind, exposed to the air but sheltered from the sun ut the two stations, being given, to find the perpendicular altitude of one station above the other.

Put B for the observed height of the Barometer at the lower station, and $b$ for that at the upper station, D for the difference of the heights of Fahts. thermoneter attached to the barometer at the two stations, and $F$ for the mean height of Falits. thermomcter exposed freely in the shade at the two stations; the altitude of the upper above the lower, will be expressed as follows in English fathoms, according to the mean of the observations of Gen. Roy, and Sir George Shuckburghb, in which the upper sign _ is used when the attached thermometer is highest at the lower station, and the lower sign + when it is lowest at the lower station.

$$
\text { L. B-L. } 6 \mp 0,4.54 \mathrm{D}-1-1-1-\mathrm{F}-320-1-0,00244
$$

i. c. Take the difference of the tabular log's of the observed heights of the barometer at the two stations, consiclering the four first figures exclusive of the inclex as wholc numbers, and the remaining figures to the right as decimals, and subtract or add T $^{5} \frac{5}{60}$ of the difference of the altitude of Faluts. thermometer (attached) at the two stations, according as it was highest at the lower or upper station; thus yuu will have the height of the upper above the lower station in English fathoms nearly, to be corrected as follows: Multiply the height found nearly, by the difference between the mean of the two al itudes of Falits. detached thermometer at the two stations and thirty-two, and by the decimal fraction 0,00244 , the product will be the correction of the approximate height, which added to, or subtracted from the same, according as the mean heights of the two altitucles of Fahts. thermometer, exposed to the air was higher or lower than 320 will give the true height of the upper station above the lower in English fathons; and easily reduced to leet. 